\title{
PENERAPAN MODEL PEMBELAJARAN KOOPERATIF TIPE INDEX CARD MATCH TERHADAP AKTIVITAS DAN HASIL BELAJAR MATEMATIKA PESERTA DIDIK
}

\author{
Fadillah Annisa ${ }^{1}$, Marlina ${ }^{2}$ \\ Universitas Negeri Padang, Sumatera Barat, Indonesia ${ }^{1,2}$ \\ Email fadillahannisa95@yahoo.co.id ${ }^{1}$
}

\begin{abstract}
Abstrak
Tujuan Penelitian ini membahas konseptual pengaruh model pembelajaran Index Card Match pada aktivitas peserta didik dan hasil belajar di sekolah dasar, menunjukkan bahwa dengan beberapa upaya yang telah dilakukan untuk membuat aktivitas anak / siswa melalui perubahan kurikulum dengan pembelajaran konvensional ke dalam pembelajaran saintifik, tetapi upaya belum dapat berjalan secara optimal, terutama kegiatan siswa yang semakin menurun, maka diperlukan upaya untuk meningkatkan proses pembelajaran, salah satunya adalah model pembelajaran kooperatif Index Card Match karena sejalan dengan terintegrasi peserta didik, berdasarkan pengamatan menunjukkan bahwa model pembelajaran Index Card Match memiliki dampak yang baik jika dinilai dari segi aktivitas dan hasil belajar, secara konseptual bahwa model pembelajaran Index Card Match dapat digunakan sebagai salah satu model yang sejalan dengan pembentukan kegiatan. dan memiliki dampak yang baik pada hasil belajar peserta didik.
\end{abstract}

Kata Kunci: Index Card Match, Aktivitas dan Hasil Belajar

\begin{abstract}
Abstrack
This article aims to conceptually discuss the effect of the Index Card Match learning model on student activities and learning outcomes in elementary schools, showing that with some efforts made to make children's / student activities through curriculum changes with conventional learning into scientific learning, but efforts have not been able to run optimally, especially student activities which are declining, so efforts are needed to improve the learning process, one of which is the Index Card Match cooperative learning model because it is in line with integrated learners, based on observations showing that the Index Card Match learning model has a significant impact both if assessed in terms of activities and learning outcomes, conceptually that the Index Card Match learning model can be used as one model that is in line with the formation of activities. and has a good impact on student learning outcomes.
\end{abstract}

Keywords: Index Card Match, Activity and Learning Outcomes

@ Jurnal Basicedu Prodi PGSD FIP UPTT 2019

$\triangle$ Corresponding author :

Address :

ISSN 2580-3735 (Media Cetak)

Email : ISSN 2580-1147 (Media Online)

Phone 
1048 Penerapan model pembelajaran kooperatif tipe Index card match terhadap aktivitas dan hasil belajar matematika peserta didik - Fadillah Annisa, Marlina

\section{PENDAHULUAN}

Pendidikan adalah penentu agar bangsa kita dapat melangkah lebih maju dan dapat bersaing dengan negara-negara lainnya. Sudah banyak usaha yang dilakukan oleh pemerintah untuk meningkatkan kualitas pendidikan di Indonesia khususnya kualitas pendidikan matematika di sekolah. Usaha tersebut diantaranya adalah perbaikan kurikulum, melengkapi sarana dan prasarana, melakukan pelatihan dan seminar bagi guru-guru. Kemerosotan kualitas pendidikan di Indonesia sudah bertahun-tahun dialami pemerintah dan masyarakat. Kondisi ini ditunjukkan berkali-kalinya kurikulum dituding sebagai penyebab kemerosotan kualitas pendidikan tersebut (Firman, 1998).

Pendidikan memiliki peranan penting bagi manusia dalam menghadapi perkembangan dan pembangunan bangsa dan negara. Pendidikan diperlukan oleh manusia untuk meningkatkan kualitas hidup, mewujudkan diri sesuai dengan tahapan tugas perkembangan secara optimal sehingga mencapai taraf kedewasaan tertentu, serta memiliki kemampuan dalam keilmuan dan ketaqwaan (Putra, 1999). Di era globalisasi dan teknologi infomasi, masyarakat Indonesia membutuhkan guru yang profesional, berkualitas, serta sebanding dengan kualitas guru negara lainnya di dunia (Firman, 2009). Dalam mewujudkan proses kegiatan pembelajaran maka yang melaksanakan proses pembelajaran tersebut dalam membelajarkan peserta didik tersebut yaitu guru. Dalam proses pembelajaran, guru melaksanakan proses kegiatan pembelajaran dengan mewujudkan perubahan tingkah laku peserta didik dengan menyampaikan materi pembelajaran.

Guru memiliki peran yang penting dalam proses belajar mengajar. Guru selalu terlibat dalam setiap proses belajar mengajar. Sebagai seorang pendidik, guru lebih banyak berhadapan dengan siswa selama proses belajar mengajar. Selain memberikan pengetahuan (transfer of knowledge) guru juga membimbing siswa, mendorong potensi siswa membangun kepribadian siswa, serta memberikan motivasi siswa dalam belajar. Oleh karena itu guru harus memiliki kreativitas yang tinggi dalam menyampaikan materi pembelajaran agar siswa tertarik dan memperhatikan dalam kegiatan pembelajaran.

Susanto (2014:186-187) menyatakan bahwa pembelajaran matematika adalah suatu proses belajar mengajar yang dibangun oleh guru untuk mengembangkan kreativitas berfikir siswa yang dapat meningkatkan kemampuan berfikir siswa, serta dapat meningkatkan kemampuan mengkonstruksi pengetahuan baru sebagai upaya meningkatkan penguasaan yang baik terhadap materi matematika. Pembelajaran matematika bukan hanya mentransfer pengetahuan saja, akan tetapi peserta didik harus menjadi subjek dalam proses pembelajaran. Dalam pembelajaran matematika harus ada keterkaitan antara konsep yang satu dengan dengan konsep yang lainnya, dan suatu penguasaan konsep menjadi prasyarat bagi konsep yang lainnya.

Pembelajaran matematika harus dikaitkan dengan realitas kehidupan, dekat dengan alam pikiran siswa dan relevan dengan masyarakat agar mempunyai nilai manusiawi. Dengan demikian pembelajaran matematika sesuai dengan ciri-ciri mtematika itu sendiri yaitu adanya alur penalaran yang logis dan memiliki pola pikir deduktif dan konsisten (Wahyuni, 2013). Tujuan utama pembelajaran matematika di sekolah adalah agar siswa memiliki kemampuan matematis yang memadai untuk melanjutkan pendidikan ke jenjang yang lebih tinggi dan untuk menyelesaikan masalah dalam kehidupan sehari-hari (Fauzan, 2013).

Dari penjelasan tersebut, dapat disimpulkan bahwa mata pelajaran matematika 
1049 Penerapan model pembelajaran kooperatif tipe Index card match terhadap aktivitas dan hasil belajar matematika peserta didik - Fadillah Annisa, Marlina

adalah mata pelajaran yang dimaksudkan untuk mengembangkan kreativitas berfikir siswa, serta dapat meningkatkan kemampuan mengkonstruksi pengetahuan baru sebagai upaya meningkatkan penguasaan yang baik terhadap materi matematika. Matematika sebuah ilmu pasti yang berkaitan dengan penalaran, bersifat abstrak, dan berpola pikir deduktif.

Untuk memperbaiki hasil belajar siswa, salah satu alternatif yang akan peneliti lakukan adalah dengan menggunakan model pembelajaran yang dapat memperbaiki hasil belajar siswa. Rusman (2014:132) mengemukakan bahwa, "Model pembelajaran adalah suatu kegiatan pembelajaran yang harus dikerjakan guru dan peserta didik agar tujuan pembelajaran dapat dicapai secara efektif dan efisien.

Berdasarkan masalah tersebut maka salah satu alternatif untuk menyelesaikan masalah yaitu dengan menerapkan model pembelajaran Index Card Match (ICM) yaitu model pembelajaran yang mencocokkan kartu yang terdiri dari dua bagian yaitu soal dan jawaban yang dicocokkan oleh siswa dengan cara berpasangan antara soal dan jawaban.

Penulis ingin menerapkan alternatif pemecahan masalah tersebut karena model ini cukup menyenangkan untuk siswa dalam mengikuti proses pembelajaran. Dengan mencari dan mencocokkan kartu berdasarkan materi pembelajaran membuat siswa memahami materi pembelajaran dengan penggunaan kartu tersebut, siswa lebih aktif saat proses pembelajaran dengan mencari pasangan kartu yang cocok antara satu dengan yang lainnya. Pembelajaran dengan Index Card Match siswa dapat belajar dengan teman sebayanya, sehingga terbentuk kerjasama antar teman sebaya. Komunikasi antar siswa akan terbangun, hal ini juga akan melatih mereka dalam menghargai pendapat siswa lain. Pembelajaran juga tidak berlangsung searah, karena ada transfer ilmu dari guru ke siswa, maupun antar siswa itu sendiri. Siswa juga tidak akan merasa bosan, karena tidak terus menerus ada di tempat duduknya. Dengan menerapkan model pembelajaran ini agar terwujudnya menghidupkan suasana kelas, belajar yang menyenangkan, yang meningkatnya keaktifan siswa dalam pembelajaran.

Tujuan pelaksanaan penelitian ini adalah untuk mendeskripsikan pengaruh model pembelajaran kooperatif tipe Index Card Match terhadap aktivitas dan hasil belajar matematika siswa sekolah dasar

Belajar secara umum diartikan sebagai perubahan pada individu yang terjadi melalui pengalaman, dan bukan karena pertumbuhan atau perkembangan tubuhnya atau karakteristik seseorang sejak lahir. Manusia banyak belajar sejak lahir. Bahkan ada yang berpendapat sebelum lahir bahwa antara belajar dan perkembangan sangat erat kaitannya. Belajar merupakan salah satu faktor yang mempengaruhi dan berperan penting dalam pembentukan pribadi dan tingkah laku individu (Venna Deski Arienta, Firman, 2017).

Selanjutnya menurut Hamalik (2012:27) menyatakan "Belajar adalah memodifikasi atau memperteguh kelakuan melalui pengalaman". Belajar itu bukan sekedar mengingat atau menghafal saja, namun lebih luas dari itu merupakan mengalami. Belajar adalah suatu proses perubahan tingkah laku individu atau seseorang melalui interaksi dengan lingkungannya.

Salah satu pertanda bahwa seseorang telah belajar adalah adanya perubahan tingkah laku pada dirinya. Perubahan tingkah laku tersebut yakni baik perubahan yang bersifat pengetahuan dan keterampilan maupun yang menyangkut sikap dan nilai afektif (Astining Rahayu, n.d.)

Slameto (2003) dalam (Ghullam Hamdu) mengemukakan bahwa belajar adalah serangkaian 
1050 Penerapan model pembelajaran kooperatif tipe Index card match terhadap aktivitas dan hasil belajar matematika peserta didik - Fadillah Annisa, Marlina

kegiatan jiwa raga untuk memperoleh suatu perubahan tingkah laku sebagai hasil dari pengalaman individu dalam interaksi dengan lingkungannya menyangkut kognitif, afektif, dan psikomotorik. Dalam belajar, siswa mengalami sendiri proses dari tidak tahu menjadi tahu.

Berdasarkan pendapat para ahli tersebut, dapat disimpulkan bahwa belajar adalah suatu aktivitas yang dilakukan seseorang dengan sengaja dalam keadaan sadar untuk memperoleh suatu konsep, pemahaman atau pengetahuan baru sehingga memungkinkan seseorang terjadinya perubahan perilaku yang relatif tetap baik dalam berpikir, merasa maupun bertindak.

Dalam kegiatan aktivitas belajar, mengajar merupakan salah satu aspek yang mempengaruhi dari aktivitas tersebut yang tergabung menjadi suatu kegiatan pembelajaran. Menurut Susanto (2014:19) "Pembelajaran merupakan bantuan yang diberikan pendidik agar terjadi proses pemerolehan ilmu dan pengetahuan, penguasaan, kemahiran, dan tabiat serta pembentukan sikap dan keyakinan pada peserta didik". Dengan kata lain, pembelajaran adalah proses untuk membantu peserta didik agar dapat belajar dengan baik.

Sejalan dengan pendapat di atas, Huda (2014:2) menyatakan "Pembelajaran dapat dikatakan sebagai hasil dari memori, kognisi, dan metakognisi yang berpengaruh terhadap pemahaman". Hal inilah yang terjadi ketika seseorang sedang belajar, dan kondisi ini juga sering terjadi dalam kehidupan sehari-hari, karena belajar merupakan proses alamiah setiap orang.

Dengan demikian pembelajaran dapat diartikan sebagai aktivitas seseorang dalam menyerap suatu informasi dan penilaian seseorang terhadap informasi yang didapatkan dan menciptakan perubahan dalam diri seseorang tersebut seperti perubahan pemahaman, keterampilan dan sikap seperti suatu kegiatan guru memberikan suatu ilmu pengetahuan terhadap siswa dalam membuat siswa menjadi aktif.

Model Pembelajaran Index Card Match merupakan model yang menggunakan kartu yang berisi pertanyaan dan jawaban dengan cara mencocokkan. Menurut Istarani (2012 : 224) Index Card Match merupakan model "mencari pasangan kartu" yang cukup menyenangkan digunakan untuk mengulangi materi pembelajaran yang telah diberikan sebelumnya. Namun demikian, materi baru pun tetap bisa di ajarkan dengan model ini dengan catatan, peserta didik diberi tugas mempelajari topik yang akan diajarkan terlebih dahulu, sehingga ketika masuk kelas mereka sudah memiliki bekal pengetahuan.

Sejalan dengan pendapat di atas, Kusuma (2015) menyatakan "Model Index Card Match diharapkan siswa dapat belajar dengan teman sebayanya, sehingga terbentuk kerjasama antar teman sebaya. Komunikasi antar siswa akan terbangun, hal ini juga akan melatih mereka dalam menghargai pendapat siswa lain. Pembelajaran juga tidak berlangsung searah, karena ada transfer ilmu dari guru ke siswa, maupun antar siswa itu sendiri”.

Menurut Silberman (2009: 240) Index Card Match adalah cara yang menyenangkan lagi aktif untuk meninjau ulang materi pelajaran. Melalui strategi ini, siswa dapat memahami materi pelajaran dengan permainan mencocokan kartu. Penggunaan strategi pembelajaran aktif index card match diharapkan dapat menimbulkan kegiatan belajar yang menarik dan menyenangkan sehingga siswa dapat memahami konsep matematika dan membantu daya ingat siswa dalam jangka waktu lama (Vinda Trinovia, 2013)

Model Index Card Match dikenal juga dengan istilah "mencari pasangan kartu". Strategi ini berpotensi membuat siswa senang dalam mengikuti proses pembelajaran. Unsur permainan yang terkandung dalam strategi ini tentunya 
1051 Penerapan model pembelajaran kooperatif tipe Index card match terhadap aktivitas dan hasil belajar matematika peserta didik - Fadillah Annisa, Marlina

membuat pembelajaran tidak membosankan

(Astining Rahayu, 2013)

Jadi, dari beberapa pendapat para ahli tersebut, dapat dibuat kesimpulan bahwa model Index Card Match merupakan model pembelajaran yang menuntut siswa untuk bekerja sama dan dapat meningkatkan rasa tanggung jawab siswa atas apa yang dipelajari dengan cara yang menyenangkan. Siswa saling bekerja sama dan saling membantu untuk menyelesaikan pertanyaan dan melemparkan pertanyaan kepada pasangan lain.

Pengajaran yang efektif adalah pengajaran yang menyediakan kesempetan belajar sendiri atau melakukan aktivitas sendiri, artinya siswa belajar sambil bekerja. Dengan demikian, mereka memperoleh pengetahuan pemahaman, dan aspekaspek tingkah laku lainnya.

Menurut Hamalik, (2012:171), “aktivitas adalah perbuatan-perbuatan yang dilakukan, termasuk perbuatan belajar dan bekerja, dimaksud untuk memuaskan perbuatan tertentu untuk mencapai tujuan tertentu pula". Asas aktivitas digunakan dalam semua jenis metode mengajar, baik metode dalam kelas maupun metode mengajar di luar kelas. Hanya saja penggunaannya dilaksanakan dalam bentuk permainan sesuai dengan tujuan yang hendak dicapai dan disesuaikan pula pada orientasi sekolah yang menggunakan jenis kegiatan itu.

Dierich (dalam Hamalik, 2012:172) menyatakan aktivitas-aktivitas yang dapat dilakukan siswa selama proses pembelajaran antara lain yaitu:

1) Kegiatan-kegiatan visual: membaca, melihat gambar-gambar, mengamati eksperimen, demonstrasi, pemeran, dan mengamati orang lain bekerja atau bermain.

2) Kegiatan-kegiatan lisan (oral): mengemukakan suatu fakta atau prinsip, menghubungkan suatu kejadian, mengajukan pertanyaan, memberi saran, mengemukakan pendapat, wawancara, diskusi, dan interupsi.

3) Kegiatan-kegiatan mendengarkan: mendengarkan penyajian bahan, mendengarkan percakapan atau diskusi kelompok, mendengarkan suatu permainan, mendengarkan radio.

4) Kegiatan-kegiatan menulis: menulis cerita, menulis laporan, memeriksa karangan, bahan-bahan kopi, membuat rangkuman, mengerjakan tes, dan mengisi angket.

5) Kegiatan-kegiatan menggambar: menggambar, membuat grafik, chart, diagram peta, dan pola.

6) Kegiatan-kegiatan metrik: melakukan percobaan, memilih alat-alat, melaksanakan pameran, membuat model, menyelenggarakan permainan, menari, dan berkebun.

7) Kegiatan-kegiatan mental: merenungkan, mengingat, memecahkan masalah, menganalisis, faktor-faktor, melihat hubungan-hubungan, dan membuat keputusan.

8) Kegiatan-kegiatan emosional: minat, membedakan, berani, tenang, dan lain-lain.

Hasil belajar adalah suatu hasil nyata yang dicapai oleh siswa dalam usaha menguasai kecakapan jasmani dan rohani di sekolah yang diwujudkan dalam bentuk rapor pada setiap semester. Suprijono (2010:5) yaitu "Hasil belajar adalah pola-pola perbuatan, nilai-nilai, pengertianpengertian, sikap-sikap, apresiasi dan keterampilan".

Sudjana (2012:22) menyatakan bahwa,"Hasil belajar adalah kemampuankemampuan yang dimiliki siswa setelah ia menerima pengalaman belajarnya. Secara sederhana, yang dimaksud dengan hasil belajar 
siswa adalah kemampuan yang diperoleh anak setelah melalui kegiatan mengajar.

Berdasarkan pendapat para ahli tersebut dapat disimpulkan bahwa hasil belajar adalah kemampuan yang diperoleh oleh siswa setelah melakukan kegiatan belajar yang mencakup ranah kognitif,afektif, psikomotor.

\section{METODE}

Penelitian ini termasuk jenis penelitian studi literatur dengan mencari referensi teori yang relefan dengan kasus atau permasalahan yang ditemukan. Referensi teori yang diperoleh dengan jalan penelitian studi literatur dijadikan sebagai fondasi dasar dan alat utama bagi praktek penelitian ditengah lapangan. Studi literatur adalah cara yang dipakai untuk menghimpun data-data atau sumber-sumber yang berhubungan dengan topik yang diangkat dalam suatu penelitian. Studi literatur bisa didapat dari berbagai sumber, jurnal, buku dokumentasi, internet dan pustaka.Data-data yang sudah diperoleh kemudian dianalisis dengan metode analisis deskriptif. Metode analisis deskriptif dilakukan dengan cara mendeskripsikan fakta-fakta yang kemudian disusul dengan analisis, tidak semata-mata menguraikan, melainkan juga memberikan pemahaman dan penjelasan secukupnya.

\section{HASIL DAN PEMBAHASAN}

Model Pembelajaran Index Card Match merupakan model yang menggunakan kartu yang berisi pertanyaan dan jawaban dengan cara mencocokkan. Menurut Istarani (2012 : 224) Index Card Match merupakan model "mencari pasangan kartu" yang cukup menyenangkan digunakan untuk mengulangi materi pembelajaran yang telah diberikan sebelumnya. Namun demikian, materi baru pun tetap bisa di ajarkan dengan model ini dengan catatan, peserta didik diberi tugas mempelajari topik yang akan diajarkan terlebih dahulu, sehingga ketika masuk kelas mereka sudah memiliki bekal pengetahuan.

Sejalan dengan pendapat di atas, Kusuma (2015) menyatakan "Model Index Card Match diharapkan siswa dapat belajar dengan teman sebayanya, sehingga terbentuk kerjasama antar teman sebaya. Komunikasi antar siswa akan terbangun, hal ini juga akan melatih mereka dalam menghargai pendapat siswa lain. Pembelajaran juga tidak berlangsung searah, karena ada transfer ilmu dari guru ke siswa, maupun antar siswa itu sendiri”.

Penggunaan strategi pembelajaran aktif index card match diharapkan dapat menimbulkan kegiatan belajar yang menarik dan menyenangkan sehingga siswa dapat memahami konsep matematika dan membantu daya ingat siswa dalam jangka waktu lama (Vinda Trinovia, 2013).

Berdasarkan hasil penelitian yang dilakukan oleh (Syahrir, 2017) bahwa setelah pelaksanaan model pembelajaran kooperatif Index Card Match terjadi beberapa perubahan sikap siswa yaitu : Kehadiran siswa mengikuti kegiatan belajar mengajar semakin meningkat. Hal ini ditandai dengan semakin berkurangnya siswa yang tidak hadir pada saat proses pembelajaran matematika, peran serta siswa untuk menjawab pertanyaan dalam proses pembelajaran semakin meningkat, ini ditandai dengan adanya kemampuan siswa untuk menemukan sendiri jawaban soal-soal yang diberikan oleh guru. Serta semakin aktifnya siswa dalam proses pembelajaran. Hal ini ditandai dengan semakin banyaknya siswa yang bertanya dan menjawab soal-soal latihan dan adanya siswa yang lain yang bisa membimbing teman yang lain.

Dari hasil review beberapa artikel yang ada terkait model pembelajaran Index Card Match penulis memilih beberapa buah artikel yang membahas mengenai aktivitas dan hasil belajar peserta didik. Pertama penelitian yang dilakukan 
1053 Penerapan model pembelajaran kooperatif tipe Index card match terhadap aktivitas dan hasil belajar matematika peserta didik - Fadillah Annisa, Marlina

oleh Ngurah, Suta, Zulaikha, Agung, \& Negara (2014) dengan judul Index Card Match Terhadap Hasil Belajar Ips Siswa Sd Jurusan Pendidikan Guru Sekolah Dasar dimana hasil penelitian menunjukkan $t_{\text {hitung }}>t_{\text {tabel }}(2.708>2.00)$, sehingga $\mathrm{H}_{\mathrm{a}}$ diterima dan $\mathrm{H}_{0}$ ditolak. Ini berarti terdapat perbedaan yang signifikan hasil belajar IPS antara siswa yang belajar melalui strategi pembelajaran aktif tipe Index Card Match dengan siswa yang belajar melalui pembelajaran konvensional. Berdasarkan hasil penelitian tersebut dapat disimpulkan bahwa strategi pembelajaran aktif tipe Index Card Match berpengaruh terhadap hasil belajar IPS siswa kelas V Gugus III Mengwi, Badung Tahun Pelajaran 2013/2014.

Berikut penelitian yang dilakukan oleh Vinda Trinovia (2013) dengan judul Penerapan Strategi Index Card Match (Mencari Pasangan Kartu) Dalam Model Pembelajaran Kooperatif Tipe Stad Pada Materi Alat Optik, Hasil penelitian menunjukkan bahwa keterlaksanaan strategi index card match dalam model pembelajaran koopertaif tipe STAD mendapat nilai 3,317 dengan kategori baik. Hasil belajar kelas eksperimen lebih baik daripada kelas kontrol dengan thitung kelas eksperimen berturut-turut sebesar 4,34 dan 3,99 dari ttabel 1,67. Respons siswa terhadap penerapan strategi index card match sebesar $88 \%$ dengan kategori sangat baik.

Selanjutnya penelitian yang dilakukan oleh Astining Rahayu dengan judul Pengaruh Model Pembelajaran Think-Pair-Share Dengan Strategi Index Card Match Terhadap Hasil Belajar Siswa Pada Standar Kompetensi Menerapkan Dasar-Dasar Elektronika Di Smk Negeri 1 Madiun. Dari pengujian hipotesis diperoleh thitung $=3,26$ dan ttabel $=1,67$ dengan signifikansi 5\%, berarti thitung $>$ ttabel. Sehingga dapat disimpulkan bahwa model pembelajaran ThinkPair-Share dengan strategi Index Card Match memiliki pengaruh terhadap hasil belajar siswa yang lebih tinggi dari pada model pembelajaran langsung pada standar kompetensi menerapkan dasar - dasar elektronika kelas X AV SMK Negeri 1. Terbukti dari hasil uji-t berada di daerah penolakan $\mathrm{H} 0$ dan terima $\mathrm{H} 1$ yang artinya hasil belajar siswa yang menggunakan model pembelajaran Think-Pair-Share dengan strategi Index Card Match lebih tinggi dari pada hasil belajar siswa yang menggunakan model pembelajaran langsung.

\section{SIMPULAN}

Berdasarkan kajian teori di atas maka dapat disimpulkan yaitu aktivitas dan hasil belajar peserta didik di sekolah dasar dengan menggunakan model pembelajaran Index Card Match lebih baik dari aktivitas dan hasil belajar matematika siswa yang menggunakan pembelajaran konvensional. Karena pembelajaran dengan menggunakan model pembelajaran Index Card Match siswa dapat bekerja sama dan saling menghargai sesama anggota kelompoknya serta siswa akan lebih semangat mengikuti pelajaran.

\section{DAFTAR PUSTAKA}

Astining Rahayu, J. A. P. (2013). Pengaruh Model Pembelajaran Think-Pair-Share Dengan Strategi Index Card Match Terhadap Hasil Belajar Siswa Pada Standar Kompetensi Menerapkan Dasar-Dasar Elektronika Di Smk Negeri 1 Madiun. Jurnal Pendidikan Teknik Elektro, 02 nomor 03, 991-999.

Daswarman. 2016. "Implikasi Pendekatan Konstruktivisme Dalam Pemecahan Masalah Matematika Bagi Siswa Sekolah Dasar". Jurnal Cerdas Proklamator. Volume : 4. No : 1 .

Fauzan, A. (2013). Pengaruh Pendekatan RME dan Kemandirian Belajar Terhadap Kemamampuan Matematis Siswa. Prosiding Semirata FMIPA Universitas Lampung, 714. 
1054 Penerapan model pembelajaran kooperatif tipe Index card match terhadap aktivitas dan hasil belajar matematika peserta didik - Fadillah Annisa, Marlina

Firman, F. (1998). Peningkatam Profesionalisasi Melalui Pertukaran Guru, 1-15.

Firman, F. (2009). Tanggung Jawab Profesi Guru Dalam Era Teknologi Informasi. Jurnal Ilmiah Ilmu Pendidikan, IX(1), 89-100.

Ghullam Hamdu, L. A. (N.D.). Pengaruh Motivasi Belajar Siswa Terhadap Pestasi Belajar Ipa Di Sekolah Dasar. Jurnal Penelitian Pendidikan, 12(1), 81-86.

Hamalik, Oemar. 2012. Proses Belajar Mengajar. Bandung: PT. Bumi Aksara.

Huda,Miftahul. 2014. Model- model Pengajaran dan Pembelajaran. Yogyakarta: Pustaka Belajar.

Ngurah, S., Suta, P., Zulaikha, S., Agung, I. G., \& Negara, O. (2014). INDEX CARD MATCH TERHADAP HASIL BELAJAR IPS SISWA SD Jurusan Pendidikan Guru Sekolah Dasar , FIP Universitas Pendidikan Ganesha EJournal Mimbar PGSD Universitas Pendidikan Ganesha.

Istarani. 2012. 58 Model Pembelajaran Inovatif. Medan: Media Persada.

Kusuma, Tri Septiana. 2015. Peningkatan Hasil Belajar Matematika Melalui Index Card Match Di Kelas V Sdn Brosot. Jurnal Pendidikan Guru Sekolah Dasar. Edisi 6 Tahun ke IV April 2015

Lufri. 2005. Metodologi Penelitian. Padang :Universitas Negeri Padang.

Putra, A. K. (1999). Efektivitas Layanan Penguasaan Konten Menggunakan Model Pembelajaran Kooperatif Tipe Think Pair Share untuk Meningkatkan Keterampilan Bertanya Siswa dalam Belajar, 0, 1-10.

Rusman. 2014. Model-model Pembelajaran. Jakarta: Raja Frafindo.

Silberman, Melvin L. 2009. Active Learning Strategi Pembelajaran Aktif. Yogyakarta: Pustaka Insan Madani.

Sudjana, Nana. 2012. Penilaian Hasil Proses Belajar Mengajar. Bandung : Remaja Rosdakarya.

Suprijono, Agus. 2010. Cooperative Learning. Yogyakarta: Pustaka Belajar.
Susanto, Ahmad. 2014. Teori Belajar Pembelajaran di Sekolah Dasar. Jakarta: Persada Media Group.

Syahrir. (2017). Application of Cooperative Learning Model Index Card Composition and Composition Functions of Functions Invers in Man 1 Mataram. Pendidikan Matematika FKIP Univ. Muhammadiyah Metro, 6(3), 414-420.

Venna Deski Arienta, Firman, Y. K. (2017). Efektifitas Layanan Penguasaan Konten Menggunakan Model Pembelajaran Role Playing Untuk Meningkatkan Kepercayaan Diri Siswa Dalam Belajar. Jurnal Ilmiah Konseling, (1), 1-8.

Vinda Trinovia, M. M. (2013). Penerapan Strategi Index Card Match (Mencari Pasangan Kartu) Dalam Model Pembelajaran Kooperatif Tipe Stad Pada Materi Alat Optik, 2(3), 85-88.

Wahyuni, S. (2013). Pengaruh Penggunaan strategi Index Card Match (Icm) Dalam Model Pembelajaran Langsung Terhadap hasil Belajar Matematika Siswa Sekolah Menengah Pertama Islam terpadu Bangkinang. Skripsi, (Icm). 